\title{
EFFECT OF COLD AQUEOUS EXTRACT OF FICUS CARCIA LEAVES ON SOME BIOCHEMICAL PARAMETERS OF BLOOD AND TISSUES IN RATS
}

Sameira M. Al-Katib

Amera A. Hamdon

Mutta'a A. Abid

Dept. of Physiology/ College of V. medicine/ Univ. of Mosul, Iraq

\begin{abstract}
Different concentrations of cold aqueous extract Ficus carcia leaves were studied on the levels of glucose, cholesterol, triglycerides, total lipids, Aspartate amino transferase (AST) and Alanine amino transferase (ALT) activity and total protein in the serum and in the liver glycogen level and total protein in the liver and heart of the normal rats. 25 male albino wistar rats derived were used, with age 3-4 month, and weight 225-300 g. The rats were divided randomly into five groups. The first group was injected with distilled water and consumed the control group. The second, third, fourth and fifth groups were injected intraperitonealy with $100,200,300$, and $400 \mathrm{mg} / \mathrm{kg} \mathrm{B} . \mathrm{W}$ with aqueous extract of Ficus carcia leaves. The blood, liver, and heart tissues were collected. The statistical results showed a significant decrease in the glucose, cholesterol, triglycerides and total lipids. While a significant increase in the Aspartate amino transferase (AST) and Alanine amino transferase (ALT) activity was showed in group 5of both compared with the control group $(\mathrm{P}<$ 0.05). In the tissues a significant reduction showed in the liver glycogen, for all concentration of the injected extract while insignificant differences were showed in the liver and heart total protein compared with the control group ( $\mathrm{P}$ $<0.05)$. It was concluded that the cold aqueous extract of ficus carcia leaves has a biochemical role in the regulation and controlling the metabolic reaction through decreasing the glucose and lipids levels.
\end{abstract}

\section{INTRODUCTION}

The fig tree (Ficus Carcia) is one of the most important fruit trees.Grows fast to 10 foot tall, tolerates summer heat and full sun. It Can with stand drough Conditions, and grows best in well- drained areas (Corner, 1995) Ficus carcia Contain number of natural enzymes such as B- gluconase , Cellulase, xylonase, and proteolytic enzymes ( Kramer and Whitaker,1964) its protein content showed large differences ( Sorensen,1996) and has low fat content (1-3)\% of dry matter (Francesch, 1995).its starch about (10-15) \% of dry matter with amylopectin more than amylose. The fruit, often sun-dride and preserved in its own sugar, has been favourite article of food since ancient times (Flora,1959). This fruit known as inflammatory agent (Mckey,1989), and used to improve the growth (Nimruzi,1998). The juice of the fruit is nutrient, demulcent and laxative, and has been much in use as agentle medicine for children. Ficus carcia has a smooth, gray and green oval leaves (Corner,1965), which are known for its pharmacological and nutritional properties (Slowing et al.,2001). Many studies used the leaves and the fruit Ficus carcia as a hypoglycemic (Perez et al.,2003), hypocholesterolemic (Canil et al., 2000) and hypotriglyceridemic agent (perez et al.,1999). Because there is no local study 
about the effect of ficus carcia, so our aim of this research is to explain the biochemical effect of the leaves aqueous extract of the local ficus carcia on the rats.

\section{MATERIALS AND METHODS}

Extract preparation: The leaves of Ficus carcia were obtained from local farms in august month. $300 \mathrm{gm}$ of leaves were Fractionated into small pecies, mixed with distilled water in ratio of $(1: 4 \mathrm{w} / \mathrm{v})$, then the mixture was homogenated with blender for $10 \mathrm{~min}$. in ice path. The process was repeated several times until the homogenization was completed. The homogenate was mixed for 1 hour in magnetic stirrer using ice bath. Then the homogenate was filtered by multiple layers of cotton, and centrifuged at 4000xg for 20-min. (Pandif et al,1979). The filtrate was lyophilized to $10 \mathrm{ml}$ and the percentage of the solid compounds was determined.

Animals groups: 25 adult Albino male weanling healthy rats derived from Wister and sprague-dawley types were used, age (3-4 months) and weight (225-300 g). The rats were divided into five groups randomly, (5 rats each).The $1^{\text {st }}$ group injected with distilled water and assumed the control group. $2^{\text {nd }}, 3^{\text {rd }}, 4^{\text {th }}$ and $5^{\text {th }}$ groups were injected intraperitonealy with the cold aqueous extract of Ficus carcia: in the following doses: 100, 200, 300, and $400 \mathrm{mg} / \mathrm{kg}$ B.W, respectively. Four hours after treatments, the animals were sacrificed under light anesthesia and the blood, liver, and heart tissues were collected for further studies.

Biochemical tests: Serum glucose, cholesterol, and triglyceride were estimated enzymatically using kit manufactured by Syrbio Company. Serum total lipid was determined using the method of Chabrol and Chardonnet (1937), AST and ALT were determined using kit manufactured by Randox company. liver, and heart total protein was determined using Biuret method (Biuret,1937), and the liver glycogen was determined using anthron method (Plumer,1978).

Statistical analysis: Standard statistical methods were used to determine the mean and standard deviation (S.D.). t-test was used to compare among subject result for various parameters among different groups tested with the control group (Bishop et al.,2005).

\section{RESULTS AND DISCUSSION}

\section{Effect of cold aqueous extract of Ficus carcia Leaves on serum glucose:}

The results in table (1) and fig (1) showed that serum glucose was significantly decrease in group 2 and 3 that injected with 100 and $200 \mathrm{mg} / \mathrm{kg} \mathrm{B.W}$ of leaves extract respectively, compared with the control group $(\mathrm{P}<0.05)$. This result was similar to that obtained by Serraclava et al.(1998) who demonstrated the hypoglycemic properties of Ficus leaves in the rats also this result was similar to the results obtained by Day (1995) Torres et al.(1999), and Pereze et al.(2003), who explained the hypoglycemic effect of the Ficus carcia leaves extract,on the diabetic

rats. Many studies referred to some organic substances that present in the medical plants such as alkaloids, guanidine, glucodides, flavonoids polysaccharides propionic acid ( Day, 1995) that responsible for lowering 
blood glucose in different ways such as stimulation of insulin secretion, or increasing the uptake of glucose by the cells ( kako et al., 1995) or act as insulin by allowing the glucose enter to the cells ( Day , 1995) or by delay the glucose a bsorption form the intestine due to its high fibers contents (Ali et al., 1995) fig. (1).

The results of serum glucose showed that there was a significant increase in serum glucose in group 4 injected with $400 \mathrm{mg} / \mathrm{kg} \mathrm{B.W}$ of the leaves extract, compared with the control group $(\mathrm{P}<0.05)$. It was suggested that the hypoglycemic effect of the leaves extract in group 2 and 3 caused a secretion of the catabolic hormones such as glucagon hormone which activate the glycogen degradation in the liver and then increase the glucose level (Murray et al.,2003).

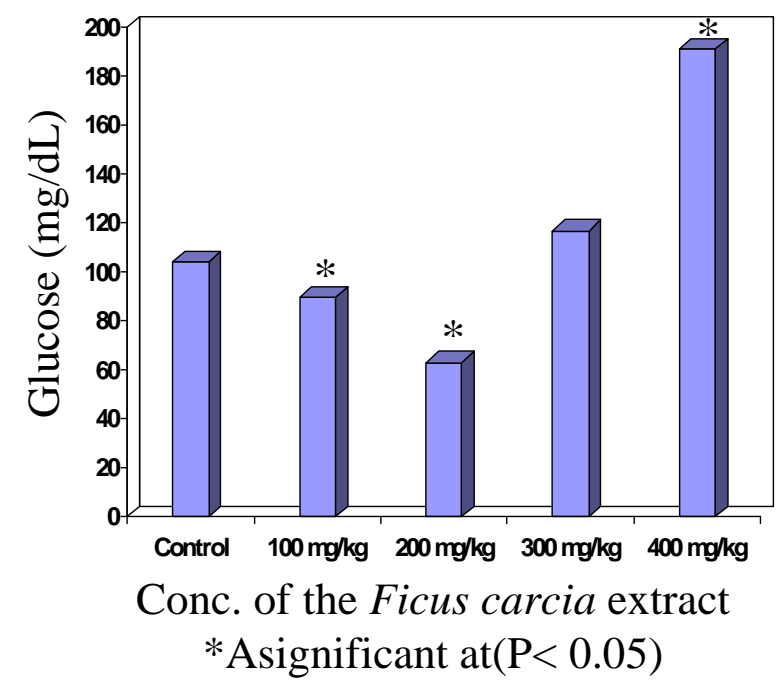

Fig. (1): Effect of cold aqueous extract of Ficus carcia leaves on serum glucose.

2.Effect of cold aqueous extract of Ficus carcia Leaves on serum cholesterol Results showed that serum cholesterol was significantly decreased in groups 2, 3 and 4 that injected with 100, 200, and $300 \mathrm{mg} / \mathrm{kg} \mathrm{B.W}$ leaves aqueous extract,compared with the control group $(\mathrm{P}<0.05)$ ( Fig 2) These results were similar with that obtained by Shukla et al.(2004) who mentioned that the water extract of Ficus leaves has a significant hypocholesterolemic effect on the rabbits. Also these results were agreed with that obtained by Slowing et al.(2001) who explained that the Ficus leaves extracts decreased total plasma cholesterol and LDL and significantly increased the HDL. Also Canal et al. (2000) mentioned that an administration of chloroform extract obtained from Ficus carcia leaves led to decline the total cholesterol levels and the ratio total cholesterol /HDL in the streptozotocin-induced diabetes rats .It was sugested that low cholesterol level may be occur due to the presence of the Flavonoids in the Ficus carcia leaves which inhibit the lipoprotein oxidation ( Kirk et al., 1998) and incrense HDL level in the blood by its antioxidant rule ( Gohlke , 2002 ) .Low cholesterol level may occur also due to the saponine compound which stimulate the secretion of bile acids from the liver and 
hydrolyzed in the digestive system to sapognine. it was showed that sapognine form non soluble complex with the bile acid go with excereta (Sauvaire et al.,1991) .

3.Effect of cold aqueous extract of Ficus carcia Leaves on serum triglyceride The results of serum triglyceride in table (1) and Fig (3) showed a significant decreasing in triglyceride level in group 3,4,and 5 that injected with 200, 300, and $400 \mathrm{mg} / \mathrm{kg} \mathrm{B.W}$ leaves extract respectively. These results were agreed with the result obtained by Perez et al.(1999) who stated the lipid catabolism activity of Ficus carcia leaves extract in the hypertriglyceridemic rats. Also, these results were agreed with the results obtained by Shukla et al.(2004) who mentioned that the flavoniods in the water extract of fig has a significant antioxidant effects in addition to hypolipidemic effect in the rabbits with hypercholesterolemia. Also Gruen and silverstein(2001) explained the rule of the Flavoniods in decreasing blood Lipids by stimulating the synthesis of Lipoprotein HDL which responsible for transferring the triglyceride to the liver and peripheras tissues.

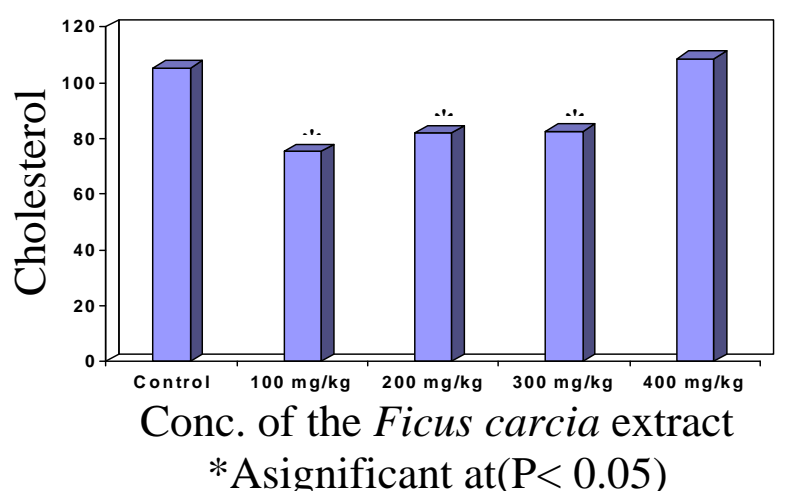

Fig. (2) :Effect of cold aqueous extract of Ficus carcia leaves on serum cholesterol.

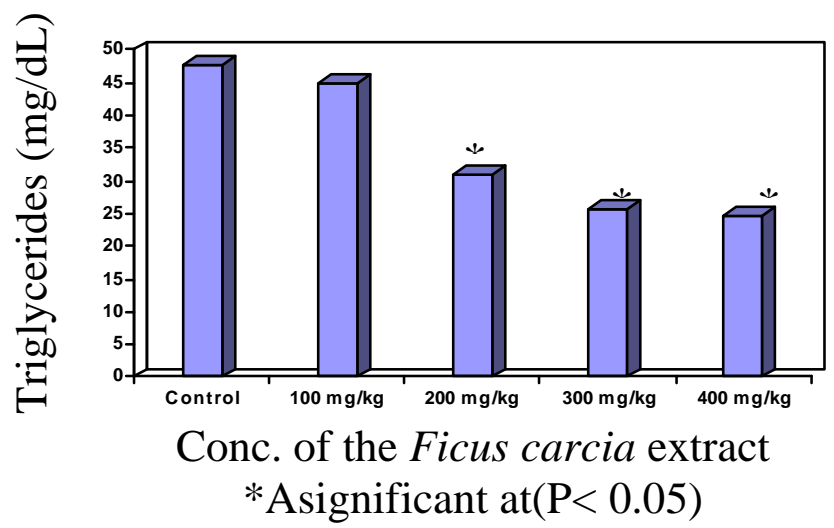

Fig.(3):Effect of cold aqueous extract of Ficus carcia leaves on serum triglycerides.

4.Effect of cold aqueous extract of Ficus carcia Leaves on serum total lipids : Table (1) and fig (4) showed asignificant decrease in total lipids level 
in groups 3 and 4 that injected with 200 and $300 \mathrm{mg} / \mathrm{kg} \mathrm{B.W}$ leaves extract, respectively, compared with the control group $(\mathrm{p}<0.05)$. These results may be support the reduction in the cholesterol and triglyceride mentioned above (Murray et al.,2003).

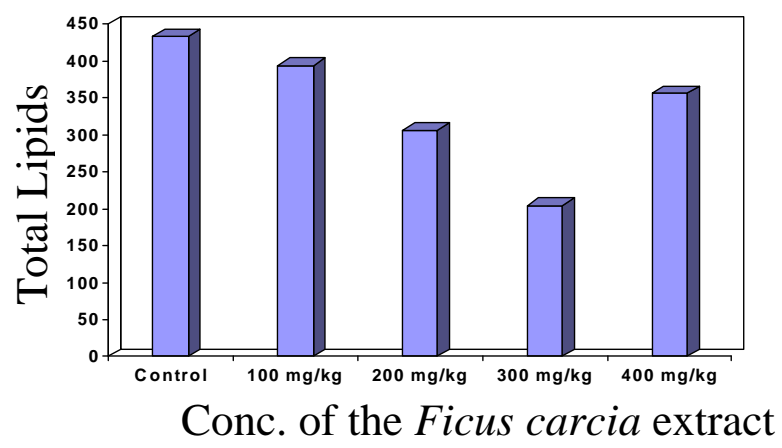

Fig. (4) :Effect of cold aqueous extract of Ficus carcia leaves on total lipids.

5.Effect of cold aqueous extract of Ficus carcia Leaves on AST and ALT activity: The results of AST and ALT activity in table (1) showed that there was a significant increase in the activity level of AST and ALT (Fig 6) in group 5 that injected with $400 \mathrm{mg} / \mathrm{kg}$ B.W leaves extract,(Fig5) compared with the control group $(\mathrm{P}<0.05)$. There is no previous studies about the effect of Ficus carcia leaves on AST and ALT activity but We can explained that group 5 showed a significant increase in glucose and cholesterol levels (table1), this increasing may be due to the secretion of the hormones antagonized insulin action such as glucagon as a result of highly decreased in glucose level showed in groups injected with 200 and $300 \mathrm{mg} / \mathrm{kg} \mathrm{B.W}$ of the extract. Also the excretion of glucagon caused an increasing in the AST and ALT activity through the increasing of transamination process (Bishop et al.,2005).

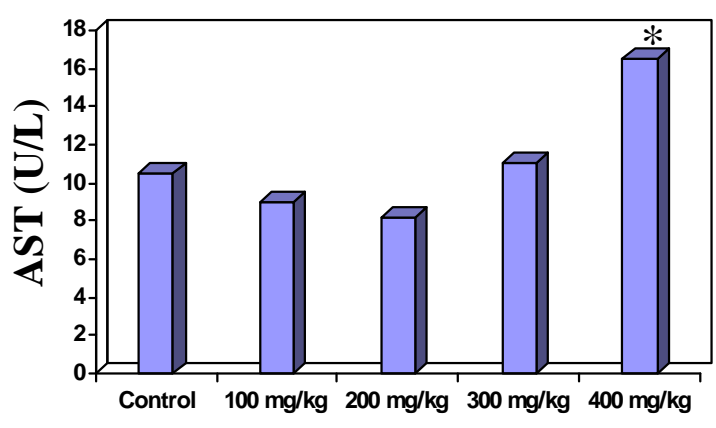

Conc. of the Ficus carcia extract *A significant at $(\mathrm{P}<0.05)$

Fig. (5) :Effect of cold aqueous extract of Ficus carcia leaves on AST activity.

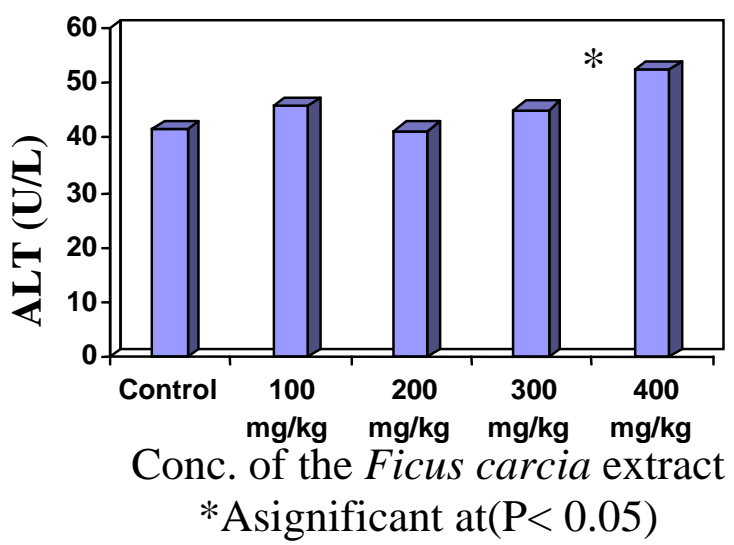

Fig.(6):Effect of cold aqueous extract of Ficus carcia leaves on ALT activity.

6.Effect of cold aqueous extract of Ficus carcia Leaves on serum total protein: Table (1) and (Fig7) showed asignificant decrease in the level of total protein in group 5 that injected with $400 \mathrm{mg} / \mathrm{kg} \mathrm{B.W}$ leaves extract Because there is no previous studies, We can conclude that the secretion of glucagon hormone in group 5 caused an increasing in the protein and amino acids 
metabolism.(Murray et al.,2003) So this result supported the increasing in AST and ALT activity showed in the same group.

Fig. (7) :Effect of cold aqueous extract of Ficus carcia leaves on serum total protein.

7.Effect of cold aqueous extract of Ficus carcia Leaves on Liver glycogen : Tabl , (2) showed the results of liver glycogen (Fig8) and also the results of liver and heart total protein (Fig9 and 10) . There were asignificant decreasing in the liver glycogen content in all treated groups that injected with 100, 200, 300 , and $400 \mathrm{mg} / \mathrm{kg} \mathrm{B.W}$ leaves extract $(\mathrm{p}<0.05)$. This result may refers to the high glycogen breakdown due to the low blood level of glucose (Murray et al.,2003). However, alterations in liver and heart total protein were not reach statistical significance, table (2).

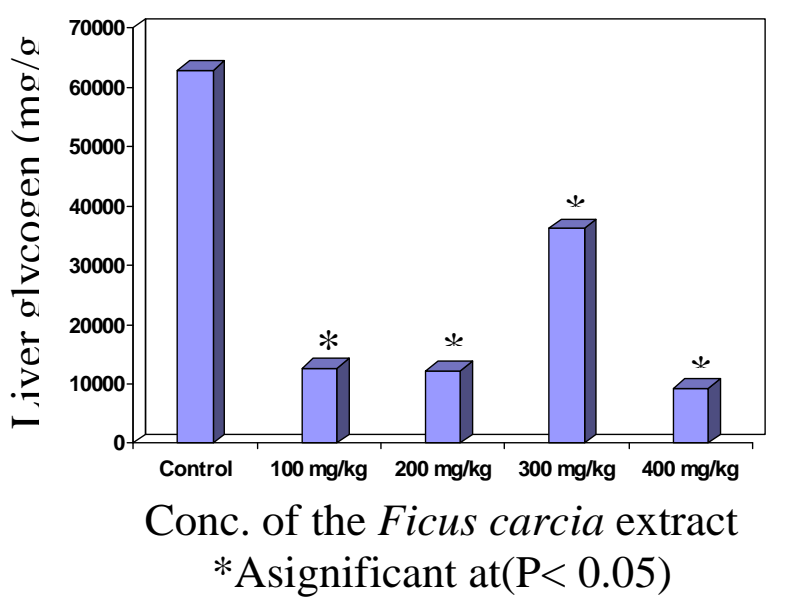

Fig. (8): Effect of cold extract of Ficus carcia leaves on liver glycogen.

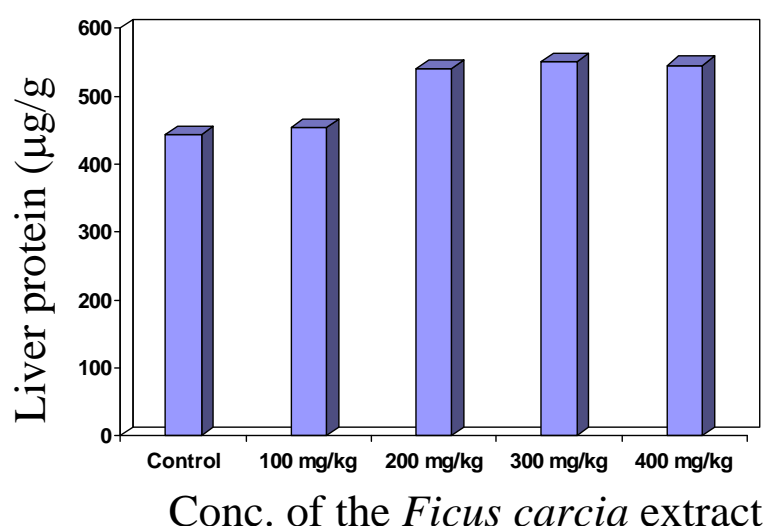

Fig. (9): Effect of cold aqueous extract of Ficus carcia leaves on liver protein.

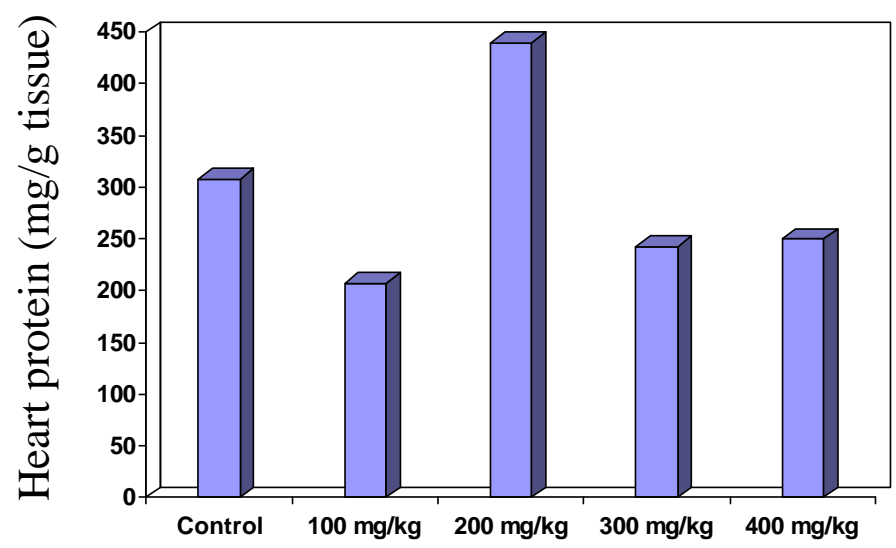


Conc. of the Ficus carcia extract

Fig. (10) Effect of cold aqueous extract of Ficus carcia leaves on heart protein: Ficus carcia is one of the important plants that have a nutritional action through decreasing of glucose and lipids levels. The mechanism of plants hypoglycemic action has not been clear, but it is suggest that the existence of flavonoids, sterols, and fibers in its structure may increase insulin releasing and activate insulin receptors, or may decrease the absorption of glucose and cholesterol from intestine, or increase the activity of liver lipoprotein lipase and hydrolysis of triglyceride (24).

Table (1): Effect of cold agueous extract of Ficus carcia leaves on the blood properties (Mean \pm S.D)

\begin{tabular}{|l|c|c|c|c|c|}
\hline \multirow{1}{*}{ Groups } & Control & $\mathrm{G}(1)$ & $\mathrm{G}(2)$ & $\mathrm{G}(3)$ & $\mathrm{G}(4)$ \\
& & $\mathrm{BW}$ & $\begin{array}{c}200 \mathrm{mg} / \mathrm{kg} \\
\text { B.W }\end{array}$ & $\begin{array}{c}300 \mathrm{mg} / \mathrm{kg} \\
\text { B.W }\end{array}$ & $\begin{array}{c}400 \mathrm{mg} / \mathrm{kg} \\
\text { B.W }\end{array}$ \\
\hline Glucose & $104.05 \pm$ & $89.79 \pm$ & $63.13 \pm$ & $117.08 \pm$ & $191.04 \pm$ \\
$\mathrm{mg} / \mathrm{dL}$ & 9.00 & $6.15^{*}$ & $2.9^{*}$ & 12.18 & $22.72^{*}$ \\
\hline Cholesterol & $105.25 \pm$ & $75.22 \pm$ & $81.97 \pm$ & $82.40 \pm$ & $108.55 \pm$ \\
$\mathrm{mg} / \mathrm{dL}$ & 10.15 & $6.83^{*}$ & $8.10^{*}$ & $5.69^{*}$ & 29.03 \\
\hline T.G & $47.65 \pm$ & $44.92 \pm 3.48$ & $30.86 \pm$ & $25.58 \pm$ & $24.69 \pm$ \\
$\mathrm{mg} / \mathrm{dL}$ & 1.69 & $5.62^{*}$ & $3.72^{*}$ & $3.69^{*}$ \\
\hline Total lipid & $432.63 \pm$ & $393.68 \pm$ & $306.03 \pm$ & $204.02 \pm$ & $355.93 \pm$ \\
$\mathrm{mg} / \mathrm{dL}$ & 19.95 & 42.55 & $39.79^{*}$ & $9.31^{*}$ & 42.90 \\
\hline AST & $10.54 \pm$ & $9.00 \pm$ & $8.16 \pm$ & $10.98 \pm$ & $16.5 \pm$ \\
U/L & 1.75 & 0.61 & 1.05 & 3.10 & $1.59^{*}$ \\
\hline ALT & $41.57 \pm$ & $45.67 \pm$ & $41.26 \pm$ & $45.06 \pm$ & $52.42 \pm$ \\
U/L & 4.36 & 3.75 & 1.35 & 2.27 & $2.33^{*}$ \\
\hline Total & $7.88 \pm$ & $7.20 \pm$ & $7.20 \pm$ & $7.52 \pm 0.24$ & $4.05 \pm$ \\
Protein g/dL & 0.54 & 0.187 & 0.21 & & 0.11 \\
\hline
\end{tabular}

*Asignificant at $(\mathrm{P}<0.05)$

Table (2): Effect of cold aqueos extract of Ficus carcia leaves on the liver and heart glycogen and total protein (Mean \pm S.D)

\begin{tabular}{|l|c|c|c|c|c|}
\hline \multicolumn{1}{|c|}{ Groups } & Control & $\begin{array}{c}\mathrm{G}(1) \\
100 \mathrm{mg} / \mathrm{kg} \\
\mathrm{BW}\end{array}$ & $\begin{array}{c}\mathrm{G}(2) \\
200 \mathrm{mg} / \mathrm{kg} \\
\mathrm{B} . \mathrm{W}\end{array}$ & $\begin{array}{c}\mathrm{G}(3) \\
300 \mathrm{mg} / \mathrm{kg} \\
\mathrm{B} . \mathrm{W}\end{array}$ & $\begin{array}{c}\mathrm{G}(4) \\
400 \mathrm{mg} / \mathrm{kg} \\
\mathrm{B} . \mathrm{W}\end{array}$ \\
\hline Liver & 62.80 & 12.736 & 12.229 & 36.165 & 9.335 \\
glycogen & \pm & \pm & \pm & \pm & \pm \\
mg/g tissue & 1.95 & $3.66^{*}$ & $4.64^{*}$ & $2.17^{*}$ & $0.607^{*}$ \\
\hline liver protein & 0.442 & 0.452 & 0.540 & 0.550 & 0.545 \\
mg/g tissue & \pm & \pm & \pm & \pm & \pm \\
& 0.041 & 0.060 & 0.036 & 0.066 & 0.077 \\
\hline
\end{tabular}




\begin{tabular}{|l|c|c|c|c|c|}
\hline Heart protein & 307.5 & 207.5 & 440 & 242.5 & 250 \\
$\mathrm{mg} / \mathrm{g}$ tissue & \pm & \pm & \pm & \pm & \pm \\
& 120.91 & 84.96 & 48.98 & 33.44 & 10.00 \\
\hline
\end{tabular}

*Asignificant at $(\mathrm{P}<0.05)$

$$
\begin{aligned}
& \text { تأثير المستخلص المائي البارد لاوراق التين في بعض الخواص الكيموحيوية للام والأنسجة في } \\
& \text { الجرذان }
\end{aligned}
$$

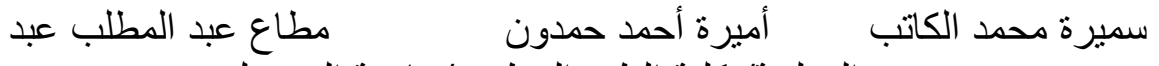

$$
\begin{aligned}
& \text { فرع الفسلجة/ كلية الطب البيطري/جامعة الموصل }
\end{aligned}
$$

\section{الخلاصة الطبري}

تم دراسة تأثير تراكيز مختلفة من المستخلص المائي البارد لأوراق التين في مستويات

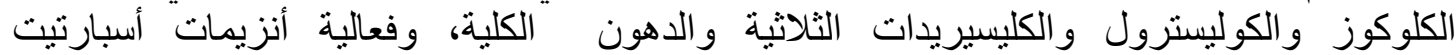

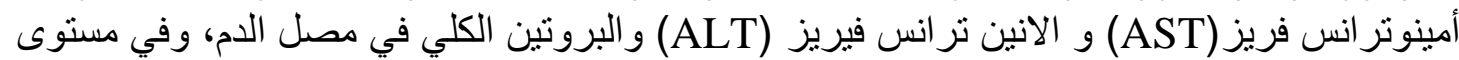

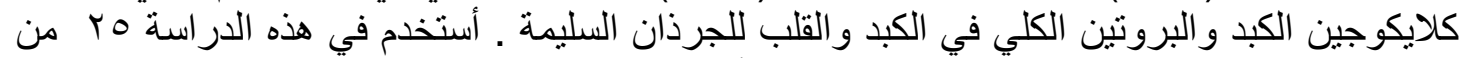

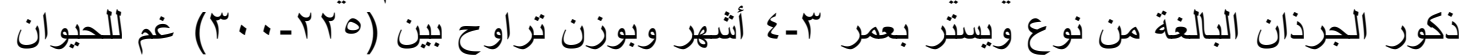

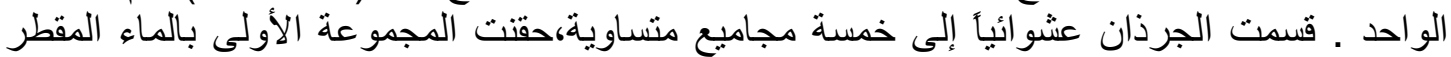

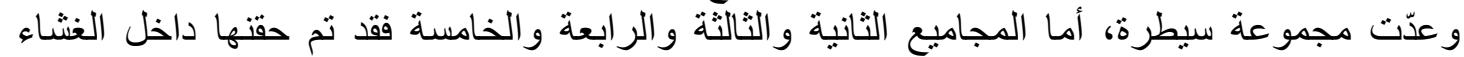

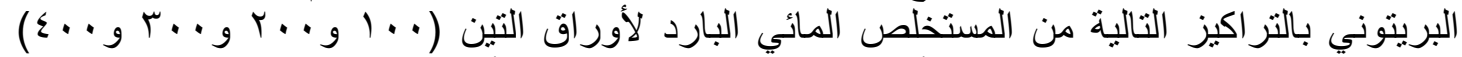

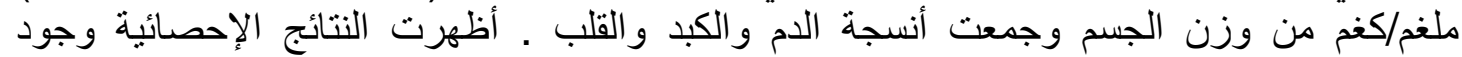

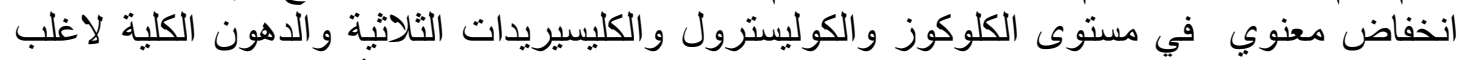
التر اكيز المحقونة من المستخلص ،في حين لوحظ ارتفاع معنوي في فعالية أنزيمات

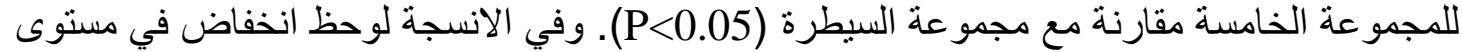

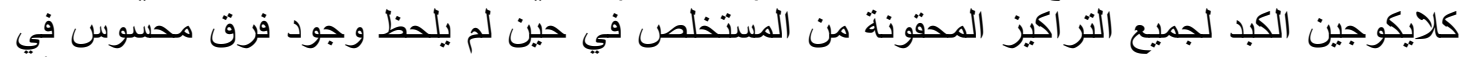

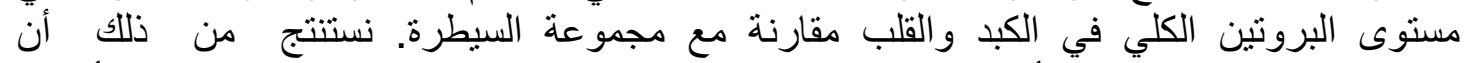
المستخلص المائي البارد "لأوراق التين له دور حيوي في التنظيم والسيطرة على العمليات الأيضية من خلال خفض مستويات الكلوكوز و المواد الدين لادنية.

\section{REFERENCES}

Ali, L; A. Azad khan; Z. Hassan; M. Mosihzzaman; N. Nahar; M. Nure-Alam and B. Rokeya (1995). Characterization of the hypoglycemic effects of Trigonella Foenum grae cum , Planta med . 61:358-360.

Bishop, M. L.; E. P. Fody; L. Schoeff (2005) "Clinical Chemistry, Principles, procedures, correlation" 5th ed. Wolters Kluwer Co., p 49-55.

Biuret (1937). Cited by Wootton I.D.P. "Microanalysis in Medical Biochemistry" 5th ed., Churchill Livingstone, Edinburgh, pp. 156-159. (1974).

Canal, J. R., M. D. Torres; A. Romero; C. Perez(2000). A chloroform extract obtained from a decotion of Ficus carcia leaves improves the cholesterolemic status of rats with streptozotocin-induced diabetes. Acta Physiol. Hung. 87(1):71-6.

Chabrol and Chardonnet (1937). Cited by Gelson Toro and Philip G Ackermann, practical clinical chemistry. Little, Brown and Company Boston (1975).

Corner, E. J. H. (1965). Check-List of Ficus in Asia and Australaisa with keys to identification. Garden's Bulletin, Singapore, 21: 1-186.

Day, C. (1995). Hypoglycemic plant compounds.Pract. Diab. Internat. , 12(6): 269-273. 
Flora of Iraq Vol.4, part (1), cornaceae to Rubiaceae (Hutchinson, 1959), Edition by C.C. Townse and Evan Guest Baghdad (1980), Minnistry of Agriculture and Agrarian Reform, Republic of Iraq.

Francesch, M. F. (1995). Euzymes supplementation of barley and sun- flower based diet . J . Appl. Poul. Res. , 4 (1):61-66.

Gohlk, H. (2002) . Nutriton and body weight.z.kardiol.,2:12-24.Gonzales, c.;demurcia , J.m;Janiak,p.;Bidouard,J,; Beauvais,c,; karray,s.;Garchon , H.and Levi- atrauss, m.(2002).Unexpected sersitivity of non bese diabeticmice with adisrupted poly (ADP- Ribose) Polymerase-1 gene to streptozotocin -induced and spon tan eous diabetes. Diabetes.51:14701476.

Gruen, D. G. and D.K. Silverstein (2001).Uruen , D G and D.K. silverstein (2001). Usual dietatary isoflavones intake is associated with cardiovascular disease risk factors in postmenopaual women . J. Nutr. 131:1202-1206 .

Ivorra, M. D.; M. Paya and A. Villar(1989). A review of natural products and plants as potential antidiabetic drugs J. Ethnopharm., 27: 243-275.

Kako, M.; T. miura; M. usami. A. kato and S. kadowai( 1995). Hyperglycemic effect of the Rhizomes of Ophiopogonis Tuber in normal and diabetic mice ." Biol. Pharm. Bull . 18(5) : 785-787.

Karmer, D. E. and J.R. Whitaker(1964). Ficus Enzymes properties of the proteolytic enzymes from the latex of Ficus carcia . J . Bciol. Chem.. 239: $2178-2183$.

Kirk, E. A.; P.Sutherland.; S. A.Wang.; A. Chaut and C. Boen (1998).Dietary isoflavones reduce plasma cholester- ol and a therosclerosis in (57BL16) mice but not LDL receptor deficientmice.J.Nutr.108(6): 954-959.

Mckey, D. (1989) Population biology of Figs: Application for conservation. Experientia, 45: 661-673.

Murray, R. K.; D.K. Granner; P. A. Mayes and V.W. Rodwell(2003). "Harper's Illustrated Biochemistry" 26th Edition ,Lange Medical Book/McGrawHill.

Nimruzis, R. (1998). Dried Ficus carcia as asource of Natural Enzymes in the chick Diet. Poultry Middle East and North Africa, 138: 34-37.

Pandif, N.N.; J.Singh and D.K Bhattacharjee (1979)."Impact of feeding chakwar (Cassia tora) seed on the growth of broilers". Indian J. Poult. SCI. 14:176 .

Perez, C.; J. R. Canal; J.E. Campillo; A. Romero and M.D. Torres(1999). Hypotriglyceridemic activity of Ficus carcia leaves in experimental hypertriglyceridemic rats. Phytother. Res., 3(3): P188-191.

Perez C.; J. R. Canal and M.D.Torres (2003). Experimental diabet treated with Ficus carcia extract effect on oxidative stress parameters. Diabetol., 40 (1): p 3-8.

Plumer, P. T. (1978). A introduction to practical Biochemistry. 2nd ed. Mc Graw-Hill book Co. U.K.Limited, pp., 345-346.

Sauvaire, y.; G. Rebes; T.C. Baccou and M.M. Loubatieres - Mariani(1991). Implication of steroid saponirs and sapogenins in the hypercholesterolemic effect of fenugreek . Lipids. 26:191-197. 
Serraclara, A.; F. Hawkins; C. Perez; J. E. Campillo; M. D. Torres (1998). Hypoglycemic action of an oral fig leaf docoction in type-1 diabetic patients. Diabetes Res. Clin. Pract., 39(1): 19-22.

Shukla, R.; Guptas; J K. Gambhir; K. M. Prabhu; P. S. Murthy (2004). Antioxidant effect of aqueous extract of the bark of Ficus bengalensis in hypercholesterolemic rabbits. J. Ethnopharmacol. 92 (1): 47-51.

Slowing, K.; P. Ganado; Z. M. San; E. Puiz; T. Tejerina (2001). Study of garlic extracts and fractions on cholesterol plasma level and vascular reactivity in cholesterol-Fed rats. J. Nutr., 131: 994-9.

Sorensen, P.(1996).Sun flower, Enzymes, Soybean. Feed International.17(12):24-28

Torres, M. D.; JR. Canal; C. Peres(1999). oxidative stress in normal and diabetic rats. Physiol. Res., 84 (3): 203-211. 